\title{
Dreams Fall Apart: People's Experience of a Development Project in Sri Lanka
}

\author{
Pradeep Dissanayake \\ Department of Town \& Country Planning, University of Moratuwa, Sri Lanka
}

dissanyk@gmail.com

\begin{abstract}
Today, "development" has become one of the most influential and dominant concepts in global political and economic discourses. For many scholars, the concept of development has become a convincing notion after the Second World War. After sixty years of development, one wonders whether developing nations were able to achieve their targets. In order to examine the link between the development discourse and the hegemonic practice, this study focuses on a particular development project carried out by the renowned NGO, World Vision, in two rural areas in Sri Lanka. I spent a month in Mahakumbukkadawala and Nawagattegama areas, to collect data and stories. The study examines the notion of development as adopted by World Vision and how the project has affected the people in these areas. Further, this research demonstrates that development is unique to the place and the people; hence, it is impossible to import, but needs to grow from within the communities and individuals.
\end{abstract}

\section{The Great Promise}

Since the late 1940s, "development" has become one of the most influential and dominant concepts in global political and economic discourses (Escobar 1995, 1997; Esteva 1992; Kapoor 2008; Sachs 1992, 2010). The entire non-Western world has pursued development at a national scale. As the "developed" nations - The United States of America and West European states - brag about their achievements, the so-called "developing" nations struggle to match the former.

Sri Lanka - an island in the northern Indian Ocean, located south of India - is not an exception. Since the country gained political independence in 1948, development has become one of the widely used terms in Sri Lanka. Since the 1950s, many elections and the government shifted several times. All political parties that contested those elections made fashionable promises using buzzwords such as progress, improvement and, ultimately, development. Constantly, political authorities and bureaucrats who assumed themselves as development experts asked the people to believe in "development" as a potential future achievement which depends on the people's commitment and sacrifice in the present.

Although, many actors engaged in development projects, which promised large national-scale results, it is questionable whether Sri Lanka has achieved the expected development and prosperity. More importantly, it is questionable whether the sixty-years of external support have actually improved the quality of life of the people of the country. This gives rise to significant questions: How do these external involvements in the name of development affect communities and individuals? Do these involvements have the honest intentions of encouraging people to meet their own aspirations? From their vantage points, how do people experience and respond to these external initiatives?

\section{The Issue(s)}

In mid-2009, immediately after my undergraduate studies, I was employed by a project consultancy group ${ }^{i}$ as a member of its survey team that worked for the well-known international NGO: World Vision. Since 1977, 
World Vision has been focusing on children, sustainability, participatory and area-based development. World Vision delivers its services to economically weak communities: It first selects a Divisional Secretariat Division ii (henceforth DS division), and then identifies communities within it (villages, in rural areas) with a larger number of people under the poverty line. In these areas, World Vision carries out Area Development Programs (ADPs) the purpose of which is to develop and empower these selected communities. The normal life span of an ADP is 12 to 15 years; once the project is completed, World Vision moves onto another location to initiate a new ADP. The survey team had two main tasks: First, to conduct awareness sessions about the 'good governance principles' for communities in two selected divisional secretariat areas: Mahakumbukkadawala and Nawagattegama. Both these are located in rural areas, in close proximity. The second task was to conduct a feedback-survey measuring the satisfaction of the people in above villages concerning the services provided by World Vision.

During preliminary visits, some people in Mahakumbukkadawela told the survey team that they are unable to continue their lives without the assistance of World Vision. In Nawagattegama, however, the people did not need any special assistance to survive. I wondered whether development aid had made Mahakumbukkadawala people dependent, i.e., as opposed to the objective of empowering the community.

The key question is: does the discourse of development which reaches ground in terms of development projects empower communities or make them dependent. Particularly, how did people live before the NGO arrived? Is it a matter of time before Nawagattegama people will also become dependent? In this context, does development aid cause dependency and impoverishment? Then, what exactly makes people dependent? Are people manipulating dependency on their own? These questions inspired me to focus this study on "development" and its impact on the communities, particularly the World Vision projects in Mahakumbukkadawala and Nawagattegama.

\section{The Concept of Development}

The Concise Oxford English Dictionary defines development as "the process of developing or being developed" (2011: 392). As a verb, it is to 'grow or cause to grow and become more mature, advanced, or elaborate'. In this sense, development is a maturing process and continuous growth. The foremost belief about development in the contemporary social sphere is its pivotal (perhaps the only) role to bring about prosperity and well-being for societies across the world.

At the end of the nineteenth century, there was a massive attraction of population to urban centers of countries and urbanization became widespread all over Europe. During the particular period, the term development combined with the urbanization process formed the term 'urban development' (Esteva, 1992). Although the notion of development was discussed in many disciplines, it still did not succeed in establishing the generalized (hegemonic) image that is associated with the world since World War II.

Since the Second World War, the entire nonWestern world has pursued development at a national scale focused on the growth of national income. After it was introduced by Harry Truman, the President of the United State, in his inaugural address in 1949, development became a dominant term in the social discourse (Escobar 1994, Esteva 1992). Europe was rebuilt immediately after the World War II. USAID helped this transformation of many European cities from rubble to modern cities. The Truman Doctrine proclaimed science, technology and capital as the main ingredients of development, and that the American Dream of peace and abundance would be extended to all peoples on the planet (Escobar 1994: 3 - 4). In Truman's speech, he mentioned poverty and lack of modern scientific knowledge as the main obstacles to the development of the people, communities and the nations in the world. Those states with such obstacles came to be known as the Third World. According to this doctrine, the undeveloped nations have to make sacrifices in order to achieve progress through enhancement of technology. The Truman doctrine, i.e., achieving rapid economic 
progress through substantial technological and industrial enhancement, defined the modern (post war) discourse of development. Development became a hard-hitting goal for the nations which did not have access to expensive technology.

When the concept of development emerged as progress or growth in the national economy, a well-known neoclassical economist, Walt Rostow (1960), brought the idea of stages of growth into the discourse. Rostow organizes economic transformation into five distinct stages to illustrate the economic evolution of history from an agrarian society to the modern era through the industrialization and the enhancement of technology. In Rostow's terms, all nations will eventually develop, and the whole planet will be industrialized one day. Also, the national economies are independent of each other. If any nation is poor or still underdeveloped, the failure of one nation to develop does not affect the others.

This idea of economic independence was highly criticized by scholars who studied the causes of the 'backwardness' of Latin American economies. These critics were commonly identified as the Dependency School. Andre Gunder Frank (1971) came up with a radical insight into underdevelopment. $\mathrm{He}$ criticizes the idea that people of underdeveloped countries are responsible for the failures of their societies to develop. According to Frank, the so called "underdeveloped" countries were caused by the developed (core) nations, as part of their development process. The underdevelopment of peripheral states (economies) is a part of the same process of development of the core states. Furthermore, he argues that the peripheral nations are intentionally kept underdeveloped because the core states require cheap raw materials, labour and new markets for their products.

Bringing the whole world together, Immanuel Wallerstein (1979) proposes the 'worldsystems perspective'; it views the core and peripheral nations as forming a single political economy which he calls the capitalist worldeconomy. He asserts the world economy emerged in the long 16th century in Europe $(1450$ - 1650). By the late 1850s, Wallerstein asserts that every country of the world had become a part of the world system. According to Frank, communities which are not a part of this system can be 'undeveloped', but not 'underdeveloped', for underdevelopment happens as part of the development process of the West. For Wallerstein, before their incorporation into the world-system, these societies are in the 'external arena.' After their incorporation, no state can completely give up Western influence (control and exploitation) at will to achieve its (independent) national development. Whatever development that takes places happens as part of the larger world-economy.

The 1990s began with many revolutionary changes in the political, economic, cultural, and geographical affairs of the world. The Union of Soviet Socialist Republic (USSR) collapsed in 1989, the Cold War between two opposing socioeconomic systems had come to a close, and the clash between the capitalist world and the communist world had come to an end.

Remarkably, some intellectuals argued that the (hegemonic) development discourse is almost dead, because its founding premises have been outdated by history (Sachs, 1992; Esteva, 1992; Escobar, 1995, 1997; Rahnema and Bawtree, 1997). They further claim that the USA may still feel that it is running ahead of other countries, but it is clear now that the race is leading towards an abyss (Ibid). In his edited volume The Development Dictionary, Wolfgang Sachs (1992) analyses the key concepts, the principles of the development discourse such as market, planning, poverty, progress, equality, etc. Each chapter indicates the transformation of those concepts from the early 1950 s to the current day. Also, it clearly emphasizes how those key principles fail to meet their original objectives.

One of the key arguments made by postdevelopment scholars is that development is a deliberately constructed discourse to maintain the so-called Third World as a development zone of the West. Elaborating this position, Arturo Escobar (1995) has encapsulated his ideas about development in Encountering Development: The Making and Unmaking of the Third World. Employing Michel Foucault's ideas of power, knowledge, and discourse, Escobar criticizes the larger edifice 
of Western ideas that supports development. $\mathrm{He}$ argues that the development discourse continues through dominant representations and prevailing institutional cultures that create the relationship between the West and the Third World. Escobar characterizes three main elements that make up the discourse of development: 1) the process of capital formation, 2) a series of cultural considerations, and 3) the creation of institutions such as the World Bank, IMF and USAID to facilitate the smooth operation of the First World. According to Escobar, the development discourse is not simply the collection of the above elements, but a system of relations established among them. For him, the idea is encapsulated in the belief that cultural, social, and political progresses are only achieved through material advancements. At the same time, development discourse is not a single or individual phenomenon but '... a system of relations ... [that] ... establishes a discursive practice' (1995:45). This particular 'discursive practice' of development comes through newly formed international organizations, government offices in distinct capitals, universities and research centers in developed countries and institutions in Third World countries. In reality, these 'experts' involved in 'abnormalizing' the normality of development would then be the same team coming up with the treatment and solutions to the problems and reforms created by them.

While development scholars continue their debates in regards to economic matters (unequal exchange, economic dependency, exploitation, control of the market, etc), Amartya Sen (1999) brings a new dimension to this debate. As they pursue economic growth, nations have neglected some important values in regard to lives and livelihoods. Often, in the mainstream society, development reflects on the growth of Gross National Product (GNP), the rise in per-capita income, or enhancement in industry and technology (Sen 1999; 3 - 11). Sen argues that states struggle to become wealthier in order to buy social goods such as education and health, but they lose sight of the development of their lives represented in 'freedom'.

For Sen, development goes beyond the accumulation of wealth and increasing the
GNP, or per-capita income. The ultimate development is freedom; freedom of the people to live as long as they wish in the way they want. To achieve development the state should remove the deprivations or the major sources of 'unfreedom' that block the achievement of freedom, for example, poverty, poor economic opportunities, neglect of public facilities, and various social discriminations. At the same time, it should want to support aspirations through, for example, more economic opportunities, political liberties, social powers and enabling conditions of good health, basic education, and the encouragement and cultivation of initiatives (Sen 1999). This approach is now appropriated by global development agencies as "capacity building".

However, after sixty years of its official launching, the concept of development is still a dream in many non-western nations. One wonders whether any of those developing nations were able to achieve their targets. A common nature in all the developing nations is the younger generation was told that they were born in a developing country, same as their seniors. However, neither the seniors nor the young have experienced any so-called development.

In the early 1990's, scholars began to argue whether development is still valid. Sachs (1992) argues that both the US hegemony and the idea of development do not exist any longer. Further, Escobar (1995) stresses that the development discourse is the creator of underdevelopment in the world. Proposing a different perspective to read development, Sen (1999) portrays that development needs to be thought beyond monetary terms and economic growth. Furthermore, he argues development is only achieved through ensuring the economic, political, and social freedoms in a society. From these arguments, we can conclude that development is not simply a concept or a theory, but a whole system of ideas that has grown since the 1950s. In other words, this whole discussion indicates development as a discursively formed dominant representation. Also, this whole development discourse is embedded within capitalism and imperialism which it represents as natural. 
However, if development is such a massive and powerful discourse, then no individual, community, or nation can simply avoid it. The crux of this discussion is, not to skip the discourse but to account for people as agents of change who respond to their subjectivity by becoming more than mere objects within the discourse. As discussed, postcolonial theory has played a significant role in this scenario. Postcolonial theory sheds light on a path to perceive human agency in the development discourse. It helps this research to go beyond the simple duality between the individuals and the development discourse. It opens up a fresh avenue to address the hybridization of local knowledge and the imported concept of development in practice.

\section{The Faith in Development}

As mentioned above, my first visit to Mahakumbukkadawala and Nawagattegama was as a member of a survey team of World Vision had been in Mahakumbukkadawala for thirteen years, since 1997, and had two years to leave the area. Therefore, besides community awareness, we were supposed to get feedback from the community concerning the services the NGO provided since 1997. In Nawagattegama, however, World Vision had arrived a year ago and its development projects were at the initial stage. We were, therefore, not looking for much feedback. However, during our good governance awareness sessions, we encouraged the community to engage in World Vision's development process.

My second visit to Mahakumbukkadawala and Nawagattegama to conduct fieldwork for this research project was in late March 2013. The changes were substantial. There was no World Vision in Mahakumbukkadawala to assist the community, and the people had survived for 3 years after the NGO left. In Nawagattegama, however, people positively participated in World Vision programs. World Vision project meetings become a part of their life. Apart from the place and the people, the past three years had also changed my vantage point of observation of both World Vision and people's agency. I no longer intended to impose mainstream development ideologies on people, but desired to experience the ways in which the communities encounter development.

\section{Poverty - the Great Enemy}

Immediately after my first meeting with the staff at World Vision's regional office in Anamaduwa town, I began walking a rutted street towards the central bus terminal. I was not alone; Prem, an Assistant Sector Coordinatoriii of World Vision, also joined me to visit some villages in the Nawagattegama area. Moreover, he desired to give a preliminary overview about World Vision's development projects in different villages.

As we walked, we began to talk about the World Vision's contribution to the development and empowerment of the community in the Nawagattegama area. Then, he explained how he got in touch with World Vision and his experience of working with communities. He also emphasized how strongly the NGO is dedicated to their goal of empowering communities in Nawagattegama. During the conversation, he described the fundamental issue affecting the community:
"Most of the people in these villages live in poverty. You can observe this everywhere in the village. Poverty is the main issue that we have to overcome. As our [World Vision's] key theme is the well-being of children $^{\text {iv }}$, we help all poor families to overcome the poverty. We strongly believe that a child could have a better life, only if the child's family has a better income. Hence, it is our duty to help the poor people to overcome poverty. Of course, we do not get a big salary for our work. Actually, this is not a job, but good enough for living. It is a great commitment to the future generation".

He sounded very confident and certain about the tasks in which he is engaged as an employee of World Vision. He strongly emphasized poverty as the main source of all hardships of the community. Indeed, not only Prem, but also the other World Vision employees that I came across during this study were certain that poverty is the main issue of the people. They were all together in wanting 
to protect people from the adversities of poverty. For instance, during my conversation with the Area Manager of World Vision in Anamaduwa, I asked; 'What made you think that these people need your help?' He was very precise:

\begin{abstract}
"It is because they are so poor and most of them are uneducated. Thus, we are here to help them and to show them the right path to overcome poverty. Believe me, we are a team and we consider our duty to serve humanity. Since we are humans, we all have a great responsibility to help each other. ...make them stronger to achieve their targets and overcome all the miseries of their lives".
\end{abstract}

This response sounds like World Vision has a God-given responsibility and they are all united in stressing that World Vision is dedicated to ensuring a better future for children by eliminating poverty and empowering the community. As the majority of the rural population in Sri Lanka is discounted from mainstream development practices, World Vision employees believe it is essential to have their kind of alternative mechanisms to assist rural communities. They all believe that they are permitted and ethical to get involved in people's life in the name of development, empowerment, well-being of life, or simply the improvement of the standard of life.

As mentioned above, the criteria that World Vision employs to select DS divisions to provide its services are based on economic conditions. World Vision employs government census and statistical information to identify DS divisions where the majority of the people live below the poverty line. When it identifies a DS division to continue its development program, World Vision informs the Divisional Secretariat $^{\mathrm{v}}$ of the area about its development program. If the divisional secretariat agrees to accept the program, it is expected to officially invite or request World Vision to carry out the development projects. In this sense, World Vision continues its development projects by invitation of the government. It also gives the impression that the project is carried out at the invitation of the state.

\section{The Categorization Process}

During these preliminary awareness sessions, World Vision groups the households in the village into four categories: (1) poorest of the poor - the poorest families in the village, (2) the poor - families which are not the poorest, but still facing substantial economic hardships, (3) moderate - most of the lower middle class families in the village belong to this category, and (4) well off - families with wealth and material possessions, assessed through the employment of the Participatory Wealth Ranking (PWR) method.

When I first exposed to these categories, I tried to apply this categorization process on myself. I was curious about how people feel and respond when they become conscious that they are poor. I also wondered how people accept these categories and their impacts over the community.

Gunarathne, a farmer and former Chairman of the World Vision's Village Development Committee (VDC) $)^{\mathrm{vi}}$ in one village in the Nawagattegama area, explained the larger development discourse:

"Based on its studies World Vision
has identified the poor families in
this village. According to World
Vision, my family is in the poor
category and I realized how poor
we are. Also, we know that we
need some [external] support to
achieve a better life. World Vision
is doing a great service in this area.
It helps people to overcome
poverty".

Due to World Vision's categorization, he was made to believe that his family belongs to the 'poor' category in the village. In fact, he was not the only person I came across who had identified himself as poor, but several other villagers believe that they are poor and need external support to survive.

World Vision's development process, when considered from a post-development 
standpoint, indicates that it constructs poverty instead of liberating the community. The development discourse which is adopted by World Vision leads people to think of themselves as poor. During its categorization process, World Vision guides the villagers to label members of their community as poor based on their material wellbeing.

Conversely, the state also actively supports World Vision to continue this construction. In that case, World Vision uses information from the government census to identify 'poor communities'. Even the government administrative agent officially invites World Vision to develop the area and empower the community. Although the project belongs to World Vision, and it has the main role, it is impossible to identify World Vision as the only actor in this poverty determination and construction process; the state and the community of the area are also involved.

\section{Dreams Fall Apart}

Compared to Nawagattegama, the story of Mahakumbukkadawela is a sharp contrast. World Vision left after its full term and the people in the Mahakumbukkadawela area no longer have external support to 'uplift' their lives. During my fieldwork, they were in a transition period in their lives. I wondered how people experienced development and empowerment after World Vision had left. Some of the people I came across were very oppressed and critical about World Vision's development process. I wondered why they were unable to achieve their goals (set by World Vision) during the last fifteen years.

Similar to Nawagattegama, World Vision had also formed a VDC for each village in Mahakumbukkadawala DS Division. With the collaboration of these VDCs, World Vision conducted many development projects in the particular area. Before it moved out of Mahakumbukkadawala after the specified fifteen-year term, following its modes of operations, World Vision opted to establish a mechanism to continue its development process into the future. In 2004, it formed an organization, 'Green Vision' vii as a body that supports World Vision's development process. Then, World Vision began to withdraw in phases, transferring its responsibilities to Green Vision.
At the beginning, Green Vision did not have its own capital; World Vision provided the initial capital for investment purposes. With World Vision's funds Green Vision started cashew nut and wood apple processing factories. As these plants were native to the Mahakumbukkadawala area, villagers sold their products to Green Vision. World Vision also arranged for one of the national grocery store chains to buy the Green Vision products. It also invested in an animal husbandry project. Under this project, members of the VDCs were given various animals such as goats, chickens, and cows; in return, the people had to take care of them for two years and return a specific number of animals, including the offspring to Green Vision.

An education fund was another important Green Vision project. Through that fund, Green Vision provided scholarships to children in poor families so that they can continue their education even World Vision left them. Other Green Vision programs included those to make attitudinal changes in the community; the youth development program is one such example. Being the backbone of all these projects, World Vision attempted to empower the community. Most people believe that it was the golden age of their villages. They all dreamt of a better future, a future without poverty and all the misfortunes of their current life.

\section{The Expired Prosperity}

In fact, the World Vision projects gave people hope, a new life, and a new beginning. This new hope inspired the community and encouraged them to work hard to achieve their dreams. If someone would visit Mahakumbukkadawala in the mid-2000s, s/he would be fascinated with the progress made by the villagers, and their courage and unity. The community would have confidently said that they could achieve their dreams of development or eradicate poverty in the next ten years. They were afraid of the withdrawal of World Vision's assistance.

Unfortunately, the reality that I observed in Mahakumbukkadawala is extremely different from what these had people originally thought and hoped for. When I asked the villagers to talk about World Vision's development 
program during my fieldwork, most of them were hesitant One said, "oh, it was many years ago. What is the point of talking about history?" Many others repeated this sentiment. According to another person "it's gone, it will never come back". However, according to Wijaya - a former Chairman of World Vision's VDC in Kandayaya for the first ten years - since World Vision moved out of Mahakumbukkadawala in 2009, his village has been like a 'tire without air'. He explained some of the root causes of the collapse of the village community: "During the last few years people became very selfish. Eventually, we lost our unity and the community was splintered into different groups."

In that sense, even though these villagers were trained to be leaders and they had participated in several workshops about the 'importance of teamwork', what they have developed through this process was not development, but individuality and a spirit of competition against one another. In addition to the community itself, some World Vision officials and employees were also responsible for the breakup of the community.

Some officials who joined the project in the last five years had created their own favorites, both individuals and groups, within the community. Some of those actions had enhanced the gap between World Vision and the community, particularly in the last few years. On the one hand, the people eventually lost confidence in World Vision's development process. On the other hand, the issues had destroyed the social harmony in the village. Daya is one of the founding social mobilizers of World Vision in Miyaellawa village in the Mahakumbukkadawala DS Division. During the interview she mentioned:

"Even several years after the departure of World Vision, people are still fighting and complain against each other. Now, most of them have forgotten about World Vision, but they continue their old resentments and suspect each other".

Right at the beginning of the project, people were informed that World Vision would not stay with them forever. Through establishing VDCs and, later, a similar supporting body, Green Vision, World Vision expected to continue its own development process. Simultaneously, it assumed that the community would be able to manage their organizations without World Vision. Actually, the key objective of the World Vision development program was building selfconfidence in the community, so that it will overcome poverty and achieve their aspirations. Instead of establishing a shortterm development program, World Vision approached the community with a long, fifteen-year program and expected the process and the momentum to continue further. Although they were organized to face their challenges, people lost their confidence immediately after the withdrawal of World Vision. Jayanath, a founding member and an employee of Green Vision, explained the situation:

"After World Vision left us, it was
very hard to find members to
continue the VDCs. They [the
villagers] assumed that they
cannot achieve anything without
the assistance of World Vision.
The community participation
dropped down to zero in many
village development committees".

According to Jayanath, only a few VDCs are still functioning in the following villages: Dangahawela, Garayakgama, Kivula Number 1, Andigama, Baranankattuwa, and Western Galkuliya. In Dangahawela, Daya continues their Committee with a few members. She makes a great effort to find new members and encourages villagers to become members of the committee. Her committee has begun to issue small loans to its members. Through this kind of strategy, she hopes to incorporate people for the development of the village. Here the key seems to be her leadership.

However, the destiny of the "people's company," Green Vision, is miserable. The company was established though a bottom-up process. The representatives of the village made all the decisions. It had a strong connection with the community at the grassroots level. In this sense, Green Vision is 
an emblem of bottom-up development. In reality, Green Vision was unable to protect any of these 'unique characteristics'. As mentioned above, there was a position of a manager apart from the board of directors. Since, most of the directors did not have enough experience to manage a company; the position of manager was established as an independent position to support those directors to make decisions. The manager became stronger and more powerful than the board of directors and eased into the position of Managing Director of Green Vision. In Jayanath's words:

\begin{abstract}
"Managing Director and the board of directors became puppets 'in manager's hand'. In practice, the manager's role changed from being an assistant to the committee to its controller. At the end of the day, manager controlled everybody and there was nobody to control the manager".
\end{abstract}

Apart from these, most of the members of the Board wanted to earn credit for the achievements of Green Vision. They increasingly focused their attention on building their personal images, instead of working as a team. When Green Vision moved away from its original objective of empowerment of the community, World Vision refused to support it. According to Jayanath, there was 'a tug of war' between the Green Vision management and World Vision. As a result, Green Vision lost its reputation among the community. Immediately after, World Vision left the Mahakumbukkadawala area, and Green Vision became a powerless organization. Eventually, Green Vision has become almost completely hopeless. It still has Rs. 3 million in its education fund; it uses the interest of that money to continue the scholars program.

In sum, the beginning of the World Vision development program in Mahakumbukkadawala was highly successful. It gave hope to the community about its development. Although World Vision had hoped to continue the development process after its departure, this vision could not continue in the absence of World Vision.
Hence, in the absence of World Vision, all its assumptions about development became fallacious. Through the withdrawal of World Vision, the entire dream of development has become distorted. This is well summed up in an idea about development that Wijaya shared with me before I left his house:
"Sir, when the government or any other organizations give aid, people become addicted to that. This country will never develop with aid. If you want to develop this country, it should stop all foreign aid. Then people will start by themselves".

\section{Conclusions}

During the whole process, World Vision has given its priority to two main groups in the society: the poor and the children. If we consider the common territories between the above groups, both are extremely vulnerable to discrimination by the mainstream society. Most of the time, they are voiceless beings in the development discourse. In mainstream development practices, they are given very limited and controlled room to represent themselves.

Since the late 1940s, World Vision and several other development agencies have given their priority to address issues related to the poor and children around the world. Identifying this aspect is the uniqueness of the development approach of World Vision. It is important to recognize the NGOs reading about the poor and the children in Nawagattegama and Mahakumbukkadawala. During this study, I understood that World Vision encountered the people and children in the project areas as victims of poverty, not survivors. All the material, monetary, and technical assistance was aimed at improving the quality of lives of those victims who needed external help. World Vision's development process reflects the worrying assumption of the passivity of the people, which deprives them of their agency. During its process, World Vision gave hope to people, but it was blind to the fact that they are agents of (under)development.

Unless it takes account of the agency of the people, a development process can never 
empower the community. Therefore, the failure of the World Vision project is understandable, but people did not recognize it. That kind of development process can never make a real change in the society, but only a temporary excitation of the people. Therefore, World Vision can never expect the community to continue its development process.

Instead of empowering them, World Vision has transformed the community into "development beings". Those beings are knowledgeable about development and their inability to achieve it. They lack the self- esteem to overcome their deprivations. When the development agency left them, these development beings become destitute in an ambiguity of the memories of their preexisting life (before the arrival of the development agency) and the knowledge they were given by the development agency. It causes these beings a great anxiety of their prevailing lives. People in Mahakumbukkadawala have already become development beings and as I believe the people in Nawagattegama are treading towards the same. 


\section{REFERENCES}

"Sri Lanka Overview." (2013) [Online]. Available: http://www.worldbank.org/en/country/srilanka /overview. (Retrieved on December 20, 2013)

Barnett, V. (2009) Marx, New York: Routledge.

Devy, G. N. (2006) A Nomad Called Thief : Reflections on Adivasi Silence. New Delhi: Orient Longman.

Dillard, A. (1974) Pilgrim at Tinker Creek. 1st U.S. ed. New York,: Harper's Magazine Press.

Escobar, A. (1995) Encountering Development: The Making and Unmaking of the Third World. Princeton, N.J.: Princeton University Press.

Esteva, G. (1992) Development. In Sachs W. (eds.), The Development Dictionary, Zed Books, New York.

Esteva, G. and Prakash M. S., (1998) Grassroots Post-Modernism: Remaking the Soil of Cultures. 1st ed.: Zed Books.

Frank, A. G. (1971) Capitalism and Underdevelopment in Latin America: Historical Studies of Chile and Brazil. The Pelican Latin American Library. Revised ed. Harmonsworth,: Penguin.

. (1979) Dependent Accumulation and Underdevelopment. New York: Monthly Review Press.

Gupta, A. (1998) Postcolonial Developments : Agriculture in the Making of Modern India. Durham: Duke University Press.

Hamdi, N. (2010) ThePlacemakers' Guide to Building Community. Tools for Community Planning. London ; Washington, DC: Earthscan.

Kapoor, I. (2008) The Postcolonial Politics of Development. Postcolonial Politics. New York: Routledge.

Gardner K, and Lewis D. (1996) Anthropology, Development and the Post-Modern Challenge [in English]. London: Pluto Press.

Malthus, T. R., and Geoffrey G. (1999) An Essay on the Principle of Population. Oxford World's Classics. New York: Oxford University Press.

Nandy, A. (2004) "The Beautiful, Expanding Future of Poverty: Popular Economics as a Psychological Defence." Economic and Political Weekly Vol. 39, no. Jan. 3-9: 94-99.

Perera, N. (2004) 'Contesting visions: Hybridity, liminality, and authorship of the Chandigarh plan,’ Planning Perspectives, 19, 2: 179-203.

Perera, N. (2010) "When Planning Ideas Land: Mahaweli’s People-Centered Approach." In Crossing Borders: International Exchanges and Planning Practices, edited by P. Healey and R. Upton, 14172. London: Routledge.

Rahnema, M., and Victoria B. (1997) The Post-Development Reader. London ; Atlantic Highlands, N.J.

Reid-Henry, S. (2012) "Arturo Escobar: A Post-Development Thinker to Be Reckoned with Drawing on Influences from Foucault to Said, the Colombian's Arguments Have a Sophistication That Often Goes Unrecognised." [Online]. Available: http://www.theguardian.com/globaldevelopment/2012/nov/05/arturo-escobar-post-development-thinker.(retrieved on January 02, 2014).

Rostow, W. W. (1960) The Stages of Economic Growth, a Non-Communist Manifesto. Cambridge Eng.: University Press.

Sachs, W. (2010) The Development Dictionary: A Guide to Knowledge as Power. 2nd ed. London ; New 
York: Zed Books.

(1992) The Development Dictionary: A Guide to Knowledge as Power. London; Atlantic Highlands, N.J.: Zed Books.

Sen, A. (1999) Development as Freedom. 1st. ed. New York: Knopf, 1999.

Spivak, G.C., Swapan C., Suzana M., and Tani E. B. Conversations with Gayatri Chakravorty Spivak. Calcutta: Seagull Books, 2006.

Wallerstein, I. (1979) The Capitalist World-Economy: Essays. Studies in Modern Capitalism. Cambridge Eng; New York: Cambridge University Press.

. The End of the World as We Know It : Social Science for the Twenty-First Century. Minneapolis: University of Minnesota Press, 1999.

- Historical Capitalism. London: Verso, 1983.

- The Modern World-System : Capitalist Agriculture and the Origins of the European WorldEconomy in the Sixteenth Century. Studies in Social Discontinuity. Text ed. New York: Academic Press, 1976.

\section{Notes}

'This consultancy group was made up of two faculty members of the University of Moratuwa where I completed my undergraduate degree.

${ }^{\mathrm{ii}}$ This is an administrative sub-unit in Sri Lanka.

iii The Area Manager is the head of the regional office. There are Program Coordinators under the manager for different sectors of concern such as education, economic development, and child sponsorship. Each program coordinator has assistants for different sectors, titled - sector coordinators to maintain a better communication between the grassroots and town office.

${ }^{\text {iv }}$ Well-being of the children is one of the main concerns of World Vision. When it selects a divisional secretariat division, it is very concerned about the child population (age 16 and below) of the particular area. During the preliminary awareness sessions, World Vision highly encourages the community to involve their children in the child sponsorship program. World Vision makes a profile for every child who would like to get a sponsor. Then, it sends these profiles to donor countries such as the USA, Australia, Canada, and United Kingdom. Subsequently any individual, a group, or an organization that becomes interested in helping these children can select a child to sponsor. As sponsors, they have to make payments of $\$ 30-\$ 40$ for a child per month to World Vision. In the World Vision process, child does not directly receive this sponsorship, but it goes to a common pool. World Vision utilizes this money for the development of the whole community instead of the particular child.

${ }^{\vee}$ The local administrative officer of the particular divisional secretariat division.

${ }^{\mathrm{vi}}$ Every village has a Village Development Committee to carry out the development projects at village level to incorporated the villagers in the development of the village. Also, committees function as the community banks in the villages and committee members are eligible to received short-term loans with a reasonable interest rate. The interest from those loans was one of the main income sources of village development committee. Committee uses this money for the development of the village.

vii Green Vision was managed by a Managing Director and a board of directors. Since, there are twenty-five village development committees in Mahakumbukkadawala divisional secretariat area, three members from each committee were appointed as the members of the main council of the company. Nine out of seventy five members of the main council were elected as the board of directors of the company. The director board appoints one of them as the Managing Director. 